\title{
Analysis Kondisi Fisik Dan Pisyologi Team Futsal Sman 3 Mataram
}

\section{Talent Identification Physical and Physiological Demands of Futsal Team SMAN 3 MATARAM}

\author{
'Maulidin, ${ }^{2}$ Nune Wire Panji Sakti, ${ }^{3}$ Herman Syah \\ Program Studi Pendididkan Olahraga dan Kesehatan, Universitas Pendidikan Mandalika, Jl.Pemuda \\ No. 59A, Mataram, Indonesia 83125 \\ Email: maulidin@ikipmataram.ac.id
}

\begin{abstract}
Abstrak
Permainan futsal memberikan manfaat bagi system ketahanan tubuh dikarena nyaris sepanjang permainan, seorang pemain berlari dengan cepat kesegala arah penjuru lapangan nyaris tanpa henti sehingga membutuhkan kondisi fisik yang prima. Setiap pemain dituntut untuk memiliki tektnik individu yang sangat baik serta kemampuan strategi bermain yang juga harus baik. Tim futsal SMA Negeri 3 Mataram dalam satu tahun ini terjadi penurunan prestasi yang sangat derastis sehingga membutuhkan kajian yang sangat serius demi mempertahankan prestasinya. Tujuan penelitian ini untuk mengidentifikasi kondisi fisik team futsal berdasarkan Komite Olahraga Nasional Indonesia (KONI). Penelitian ini dilakukan di lapangan SMA Negeri 3 Mataram, dan Laboraturium Fakultas Ilmu Keolahragaan dan Kesehatan Masyarakat. Sampel yang digunakan seluruh team futsal yang berjumlah 12 orang yang bersedia secara sukarela. Instrumen tes yang digunakan dalam penelitian ini; Multistage Test untuk mengukur daya tahan kardiorespirasi; Leg and Back Dynamometer mengukur kekuatan otot tungkai; lari 60 meter mengukur kecepatan; Sutel Run Test mengukur kelincahan dan Standing Broad Jump mengukur power otot tungkai. Data yang dikumpulkan dianalisis menggunakan persentase komulatif. Hasil penelitian daya tahan aerobik dengan kategori baik (75\%); kekuatan otot tungkai dalam kategori baik (50\%); kecepatan dalam kategori baik $(83.3 \%)$; kelincahan dalam kategori baik $(50 \%)$ dan power otot tungkai dalam kategori baik (58.3\%). Kesimpulan kondisi fisik yang dimiliki team futsal SMA Negeri 3 Mataram sebagian besar baik dan perlu ditingkatkan, ada sebagian komponen fisik yang kategori kurang.
\end{abstract}

Kata Kunci: Daya tahan aerobic, kekuatan otot, kecepatan, kelincahan, power otot, futsal

\section{Abstract}

Futsal games provide benefits for the endurance system because almost throughout the game, a player will run speed in all directions across the field almost without stopping so that requires excellent physical condition. Each player is required to have excellent individual techniques and good playing strategy skills. The futsal team of SMA Negeri 3 Mataram in one year saw a decline in achievement that was so drastic that it required a very serious study to maintain its achievements. The purpose of this study was to identify the physical condition of the futsal team based on the Indonesian National Sports Committee (KONI). This research was conducted in the field of High School 3 Mataram, and the Laboratory of the Faculty of Sport Science and Public Health. The sample used by the entire futsal team was 12 people who volunteered. The instrument test used in this study; Multistage Test to measure cardiorespiratory endurance; Leg and Back Dynamometer measures leg muscle strength; run 60 meters measuring speed; Sutel Run Test measures agility and Standing Broad Jump measures leg muscle power. Data collected were analyzed using cumulative percentages. The results of aerobic endurance research in the good category $(75 \%)$; leg muscle strength in the good category (50\%); speed in the good category (83\%); agility in the good category (50\%) and leg muscle power in the good category (58\%). Conclusion, the physical condition of the futsal team of SMA Negeri 3 Mataram is mostly still lacking so it needs to be improved, there are some physical components that are good. 


\section{PENDAHULUAN}

Futsal adalah perminan sepak bola dalam ruangan. Permainan ini sendiri dilakukan oleh lima pemain setiap team, berbeda dengan sepak bola yang permainnya berjumlah sebelas orang setiap tim. Ukuran bola dan lapangannya pun lebih kecil dibandingkan ukuran yang digunakan dalam sepakbola. Sedangkan peraturan futsal dibuat sedemikian ketat oleh FIFA agar permainan ini berjalan dengan fair play dan juga untuk menghindari cidera yang dapat terjadi. Peraturannya sangat ketat, yaitu pemain dilarang melakukan tackling dan sliding keras. Untuk dapat mencapai prestasi yang baik, atlet perlu memiliki komponen kebugaran fisik yang baik. Komponen utama kebugaran fisik pemain futsal adalah kekuatan otot, daya tahan otot, kekuatan otot, fleksibilitas, dan daya tahan aerobic, (Tanri A., dkk, 2015)

Permainan putsal adalah permainan invasi (invasition game) yang dimainkan oleh lima lawan lima orang dalam durasi tertentu yang dimainkan pada lapangan, gawang, dan, bola relatif kecil daripermainan sepakbola. Yang mensyaratkan kecepatan bergerak menyenangkan serta aman dimainkan serta team yang menang adalah team yang lebih banyak mencetak gol ke gawang lawannya (Agus Suworo D.M, dkk 2009). Permainan ini juga memberikan manfaat bagi sistem ketahanan tubuh karena nyaris sepanjang permainan, seorang pemain akan berlari ke segala arah penjuru lapangan, nyaris tanpa henti. Menurut Andri Irawan (2009) teknikteknik dasar dalam bermain futsal ada beberapa macam, seperti receiving (menerima bola), shooting (menendang bola ke gawang), passing (mengumpan), chipping (mengumpan lambung), heading (menyundul bola), dan dribbling (menggiring bola)

Permainan futsal memberikan manfaat bagi system ketahanan tubuh dikarena nyaris sepanjang permainan, seorang pemain akan berlari dengan cepat kesegala arah penjuru lapangan nyaris tanpa henti sehingga membutuhkan kondisi fisik yang prima. Setiap pemain dituntut untuk memiliki tektnik individu yang sangat baik serta kemampuan strategi bermain yang juga harus baik. Namun, yang tidak kalah pentingnya adalah segi fisik yang kadang kala menjadi persoalan dalam persaingan perebutan prestasi tertinggi dalam bidang olahraga di Indonesia pada umumnya dan futsal pada khususnya. Menurut Justinus Lhaksana (2011), sehebat apapun seorang pemain dalam hal teknik dan taktik tetapi tanpa disadari oleh kondisi fisik yang baik maka prestasi yang diraih tidaklah sama dengan pemain yang memiliki kemampuan teknik, strategi, dan tentunya kondisi yang baik.

Pencapaian prestasi yang baik, perlu bagi atlet untuk memiliki komponen kebugaran fisik. Kebugaran komponen fisik yang dominan untuk pemain futsal adalah kekuatan otot, daya tahan otot, kekuatan otot, fleksibilitas, dan daya tahan aerobik. (FIFA, 2012) Sebelumnya hasil investigasi dari para ahli dan pelati futsal (Green, 1992; Al-Hazzaa et al., 2001) telah menganalisis profil fisiologis dan antropometrik yang ideal bagi pemain futsal yang sebagian besar sukses dari Eropa Barat dan Amerika. Aspek komponen fisik yang dominan seperti, komposisi tubuh, daya tahan, keseimbangan antara kekuatan anaerob dan kekuatan aerobik, adalah yang terpenting dalam evaluasi pemain elit (Shephard, 1999; Ostojić, \& Zivanić, 2001; Ostojić, 2003a).

Dalam bermain futsal dituntut untuk memiliki kondisi fisik yang baik guna pencapaian prestasi yang baik (Ricardo A. B., et al 2016; Castagna C., et al 2006). Dalam pertandingan futsal fosforilasi oksidatif bertanggung jawab sekitar $76 \%$ dari semua energi yang disintesis ulang dalam pertandingan dengan rata-rata penyerapan oksigen sekitar 48, $6 \mathrm{~mL} \quad \mathrm{~kg} \quad-1-1$, menunjukkan bahwa aerobic metabolisme mungkin menjadi faktor penting dalam bermain futsal; oleh karena itu, pengembangan kapasitas fisik ini penting untuk atlet untuk mencapai performa tinggi dalam olahraga (Alvarez JC., et al 2009; Castagna C, D., 2009).

Futsal merupakan olahraga yang membutuhkan tuntutan spesifik untuk kinerja fisik yang baik (Castagna C, et al, 2006., Oliveira RS, aet al, 2013)), di mana fosforilasi oksidatif bertanggung jawab untuk menyuplai energy sekitar $76 \%$ dari semua energi yang disintesis ulang dalam pertandingan dengan rata-rata penyerapan oksigen sekitar 48,6 
mL.kg-1-1 menunjukkan bahwa metabolisme aerobic menjadi faktor penting yang harus dimiliki atlet futsal. Oleh karena itu, pengembangan kapasitas fisik ini penting untuk atlet dalam mencapai performa tinggi dalam olahraga (Alvarez JC, et al, 2009; Castagna C, et al 2009)

Sementara itu, dalam pertandingan futsal ada momen-momen penting yang membutuhkan Intensitas harus tinggi dengan durasi pendek (Barbero-Alvarez JC., et al, 2008; Gorostiaga EM, et al, 2009) Berdasarkan Castagna et al. (2009), momen-momen penting selama pertandingan menunjukkan kinerja sistem anaerob yang tinggi dengan kecepatan berlari 20-30 detik, dengan rata-rata konsentrasi laktat sekitar $5.3 \mathrm{mmol}$ Lmin dan puncak $80-85 \%$ terhadap kinerja maksimal (Soares-Caldeira LF, et al, 2014)

Penilaian langsung dalam pertandingan futsal kebutuhan $\mathrm{VO}_{2}$ pemain harus dapat bekerja pada intensitas $50-55 \mathrm{ml} \cdot \mathrm{kg}^{-1} \cdot \mathrm{min}^{-1}$ untuk bermain futsal secara profesional. (Bangsbo, J. et al., 1991. McInnes SE, et al, 1995) Studi sebelumnya telah menyarankan pentingnya tingkat daya aerobik yang tinggi, untuk mendorong pemulihan yang lebih cepat (misalnya pemulihan PCr yang ditingkatkan) di antara upaya yang sangat intensif atau bahkan setelah kelelahan. Tomlin DL, et al, 2002) Namun, sesuai dengan masa dan usia Pedro et al (2013) menemukan bahwa baik $\mathrm{VO}_{2 m a x}$ maupun $\mathrm{VO}_{2}$ (pada beban kerja yang sama) berbeda antara pemain futsal profesional dan semi-profesional.

Para peneliti juga menemukan bahwa $\mathrm{VO}_{2}$ max dan $\mathrm{VO}_{2}$ di VT tidak berbeda secara signifikan. Di Sebaliknya, Alvarez et al. 15 membandingkan VO2max, VT, dan ekonomi berjalan dari pemain futsal dari tingkat kompetitif yang berbeda untuk menentukan apakah kebugaran aerobik adalah variabel diskriminatif untuk keberhasilan futsal. Studi ini menemukan bahwa pemain futsal profesional memiliki nilai VO2max yang jauh lebih tinggi ( 62.8 vs $55.2 \mathrm{ml} . \mathrm{kg}^{-1} \cdot \mathrm{min}^{-1}$ ) dan nilai VO2 dari pada temm semi-profesional. Para pemain futsal profesional menunjukkan VO2 yang jauh lebih tinggi di VT dari pada pemain semi-profesional. Temuan ini dikaitkan dengan karakteristik futsal, olahraga intermiten intensitas tinggi yang terkait dengan komponen anaerob yang signifikan dan sebagian besar pertandingan dan sesi pelatihan para pemain futsal elit selama sesi kompetisi (Bangsbo J, et al, 191).

Kecepatan berlari dalam bermain futsal membutuhkan VO2max lebih tinggi pemain futsal profesional dibandingkan dengan pemain semi-profesional (Pedro RE., et al, 2013) Temuan ini sama dengan hasil penelitian yang dilakukan oleh Ziogas et al. (2013) yang menunjukkan kecepatan lari di ambang laktat dapat membedakan karakteristik daya tahan pemain sepak bola dari tingkat kompetitif yang berbeda lebih akurat daripada VO2max. Hasil ini menunjukkan bahwa kecepatan yang terkait dengan $\mathrm{S}-\mathrm{VO}_{2}$ max dan VT (SVT) juga harus diperhatikan dalam pemain futsal karena dapat mencerminkan perbedaan tingkat kompetitif dalam pertandingan (Ziogas et al. 2013)

Penurunan prestasi team futsal SMA 3 Matara dalam 7 bulan terakhir ini perlu dicermati dan mendapat kajian yang serius demi perkembangan prestasinya kedepan. Dalam upaya meningkatkan prestasi dalam olahraga futsal, faktor kondisi fisik menjadi sangat penting. Kondisi fisik yang baik diperlukan oleh atlet dalam setiap cabang olahraga guna menunjang pelaksanaan teknik dan taktik saat berlatih atau bertanding. Kondisi fisik yang baik merupakan salah satucara untuk pencapaiaan prestasi. Menurut Sajoto (1988) kondisi fisik adalah satu prasyarat yang sangat diperlukan dalam usaha peningkatan prestasi seorang atlet, bahkan dapat dikatakan sebagai keperluan dasar yang tidakdapat ditunda atau ditawar lagi.

Program latihan kondisi fisik haruslah direncanakansecara baik dan sistematis dan ditujukan untuk meningkatkan kesegaran jasmanidan kemampuan fungsional dari sistem tubuh sehingga dengan demikian memungkinkan atlet untuk mencapai prestasi yang lebih baik (Harsono, 1988).

\section{METODE}

Dua belas pemain futsal pria (umur \pm 16 tahun, berat badan $\pm 61 \mathrm{~kg}$ dan tinggi badan $\pm 169 \mathrm{~cm}$ ) terdiri dari dua penjaga gawang, dua pemain belakang, enam elandang sayap, dan dua 
penyerang. Instrument yang digunakan Multistage Test mengukur daya tahan kardiorespirasi denganl validity dan reliabilitas sebesar 0.860. Satuan dari tes ini adalah $\mathrm{kg} / \mathrm{ml} / \mathrm{min}$, Leg and Back mengukur Kekuatan otot tungkai, lari 60 meter mengukur kecepatan, satuan tes detik, Sutel Run Test mengukur kelincahan dan Standing Broad Jump mengukur Power otot tungkai. Analisis data menggumakan persentase komulatif dengan kategori; Baik Sekali, Baik, Sedang, Kurang, dan Kurang Sekali.

\section{HASIL DAN PEMBAHASAN}

Deskripsi data kondisi fisik yang dimiliki team Futsal SMA Negeri 3 Mataram. Dapat dilihat pada table 1. Setelah mengikuti serangkaian tes meliputi; Daya tahan jantung menggunakan tes (Multistage Test.), Kekuatan otot tungkai menggunakan tes (Leg and Back Dynamometer), Kecepatan menggunakan tes (lari 60 meter), Kelincahan menggunakan tes (Sutel Run Test), dan Daya ledak otot tungkai menggunakan tes (Standing Broad Jump). Data menggumakan persentase komulatif dengan kategori; Baik Sekali, Baik, Sedang, Kurang, dan Kurang Sekali.

Tabel 1. Distribusi Frekuensi komponen fisik Tim futsal SMA Negeri 3 MataramDaya Tahan Jantung

\begin{tabular}{|c|c|c|c|c|c|}
\hline \multirow[t]{2}{*}{ No } & \multirow[t]{2}{*}{ Komponen Fisik } & \multirow[t]{2}{*}{ Kelas Interval } & \multicolumn{2}{|c|}{ Frekeunsi } & \multirow[t]{2}{*}{ Kategori } \\
\hline & & & Absolut (Fa) & Relatif \% & \\
\hline \multirow[t]{5}{*}{1} & $\begin{array}{l}\text { Daya Tahan } \\
\text { Jantung }\end{array}$ & $>103$ & 2 & $16.7 \%$ & Baik Sekali \\
\hline & & $103-79$ & 7 & $58.3 \%$ & Baik \\
\hline & & $78-56$ & 2 & $16.7 \%$ & Sedang \\
\hline & & $57-29$ & 1 & $8.3 \%$ & Kurang \\
\hline & & $<29$ & 0 & $0 \%$ & Kurang Sek: \\
\hline \multirow[t]{5}{*}{2.} & Kekuatan Otot & $>103$ & 1 & $8.3 \%$ & Baik Sekali \\
\hline & Tungkai & $103-79$ & 5 & $41,7 \%$ & Baik \\
\hline & & $78-56$ & 4 & $33.3 \%$ & Sedang \\
\hline & & $57-29$ & 1 & $8.3 \%$ & Kurang \\
\hline & & $<29$ & 1 & $8.3 \%$ & Kurang Sek: \\
\hline \multirow[t]{5}{*}{3.} & Kecepatan & $<3,90$ & 1 & $8.3 \%$ & Baik Sekali \\
\hline & & $3,90-4,29$ & 9 & $75 \%$ & Baik \\
\hline & & $4,30-4,69$ & 2 & $25 \%$ & Sedang \\
\hline & & $4,70-5,00$ & 0 & $0 \%$ & Kurang \\
\hline & & $>5,00$ & 0 & $0 \%$ & Kurang Sek: \\
\hline \multirow[t]{5}{*}{4.} & Kelincahan & $<15,20$ & 2 & $16.7 \%$ & Baik Sekali \\
\hline & & $15,20-16,19$ & 4 & $33.3 \%$ & Baik \\
\hline & & $16,20-18,19$ & 3 & $25 \%$ & Sedang \\
\hline & & $18,20-19,30$ & 2 & $16.7 \%$ & Kurang \\
\hline & & $>19,3$ & 1 & $8.3 \%$ & Kurang Sek: \\
\hline \multirow[t]{5}{*}{5.} & $\begin{array}{l}\text { Power Otot } \\
\text { Tungkai }\end{array}$ & $>279$ & 1 & $8.3 \%$ & Baik Sekali \\
\hline & & $254-279$ & 6 & $50 \%$ & Baik \\
\hline & & $220-253$ & 3 & $25 \%$ & Sedang \\
\hline & & $190-219$ & 1 & $8.3 \%$ & Kurang \\
\hline & & $<190$ & 1 & $8.3 \%$ & Kurang Sek: \\
\hline
\end{tabular}

Dijelaskan bahwa daya tahan jantung tim futsal SMA Negeri 3 Mataram terdapat 2 siswa dengan katergori "Baik Sekali" (16.7\%), 7 siswa dengan kategori "Baik" (58.3\%), 2 siswa dengan kategori "Sedang" (16.7\%), 1 siswa dengan kategori "Kurang" (8.3\%). Kekuatan Otot tungkai; terdapat 1 siswa dengan katergori "Baik Sekali" (8.3\%), 5 siswa dengan kategori "Baik" (41.7\%), 4 siswa dengan kategori "Sedang" (33.3\%), 1 siswa dengan kategori "Kurang" (16.67\%) dan 1 siswa dengan kategori "Kurang Sekali" (8.3\%). Kecepatan; terdapat 1 siswa dengan katergori "Baik Sekali" (8.33\%), 9 siswa dengan kategori "Baik" (75\%), 2 siswa dengan kategori "Sedang" (16.7\%). Kelincahan; terdapat 2 siswa dengan katergori "Baik Sekali" (16.67\%), 4 siswa dengan kategori "Baik" (33.3\%), 3 siswa dengan kategori "Sedang" (16.7\%), 2 siswa dengan kategori "Kurang" (16.67\%) dan 1 siswa dengan kategori "Kurang Sekali" (8.3\%). Daya ledak otot tungkai; terdapat 1 siswa dengan katergori "Baik Sekali" (8.33\%), 6 siswa dengan kategori "Baik" (50\%), 3 siswa dengan kategori "Sedang" (25\%), 1 siswa dengan kategori "Kurang" (8.33\%) dan 1 siswa dengan kategori "Kurang Sekali" (8.33\%).

Hasil penelitian analisis daya tahan aerobik Tim Futsal SMA Negeri 3 Mataram (75\%); dengan kategori baik dengan rata-rata 47.8, secara keseluruhan team futsal dapat dikatakan baik, tetapi ada juga sebagian atlet masih kategori kurang, hal ini disebabkan 
kurang maksimalnya mengikuti latiahan yang di berikan pelatih. Daya tahan jantung paru memengaruhi berapa lama pemain mampu bermain dalam lapangan. Pemain yang mempunyai daya tahan jantung paru yang baik mampu untuk bermain selama 40 menit sebaliknya jika seorang pemain mempunyai daya tahan jantung paru rendah, akan cepat kehabisan tenaga sebelum pertandingan selesai. Dalam bermain futsal dituntut harus memiliki kondisi fisik yang baik (Castagna C, et al 2006) dimana fosforilasi oksidatif bertanggung jawab menyediakan energy sebesar $76 \%$ dari total energy yang digunakan dalam pertandingan dengan rata-rata penyerapan oksigen sekitar 48,6 mL.kg-1-1, menunjukkan bahwa aerobic metabolisme mungkin menjadi faktor peting dalam bermain futsal atlet untuk mencapai performa yang tinggi (Alvarez JC, et al 2009).

Hasil tes kekuatan otot tungkai team futsal $(50 \%)$ dalam kategori baik, hal ini menunjukkan bahwa kekuatan otot tungkai berada kategori sedang. Keadaan ini masih jauh dari harapan untuk dapat memiliki kekuatan otot tungkai yang baik sebagai pemain futsal. Latihan kekuatan otot sangat kurang, karena pada sesi latihan sering kali lebih mengutamakan latihan tekhnik dan taktik. Padahal latihan kekuatan otot tungkai dan punggung bisa dilakukan dengan cara sederhana yakni dengan gerakan lunge, squat, back up, dan latihan pliometrik lainnya. Pemain harus mampu berdiri kuat dan seimbang dalam melakukan gerak yang luas dalam permainan. Kekuatan yang baik mendorong pemain bergerak dan bertahan dengan baik. Kekuatan otot tungkai berpengaruh pada kecepatan lari kelincahan, shooting, dan kemampuan melakukan teknik dasar dengan bola. Otot tungkai menjadi tumpuan yang utama dala permainan futsal ( $R$. Muhammad dkk, 2015).

Selanjutnya secara umum hasil tes kecepatan team futsal $(83.3 \%)$ dalam kategori baik. Perbandingan antara berlari dan berjalan pada permainan futsal 1:1 (Naser dkk, 2017) Intensitas dalam pertandingan futsal terbukti lebih tinggi dari pemain sepakbola (BarberoAlvarez JC. et al, 2008). Pada pemain futsal profesional mencakup $13.7 \%$ dari total intensitas (kecepatan $\geq 15 \mathrm{~km} . \mathrm{h}^{-1}$ dan $8.9 \%$ berlari (kecepatan berlari $\leq 25 \mathrm{~km} \cdot \mathrm{h}^{-1}$ ) (Barbero Alvarez J, et al, 2004) pemain melakukan 8,6\% kegiatan per menit selama pertandingan (Barbero Alvarez J, et al, 2007). Selain itu, pemain melakukan upaya intensitas rendah setiap 14 detik, upaya intensitas sedang setiap 37 detik, dan intensitas tinggi setiap 43 detik, upaya intensitas maksimum setiap 56 detik, (Barbero-Alvarez JC. et al, 2004). Hasil penelitian ini sejalan dengan penelitian yang dilakukan oleh Pedro RE, et al. (2013) Kecepatan berlari di ambang ventilasi (VT) dan VO2max lebih tinggi pada pemain futsal profesional dibandingkan dengan pemain semi-profesional dan temuan ini juga sejalan dengan yang dilaporkan oleh Ziogas et al, 2011) yang menunjukkan kecepatan lari di ambang laktat dapat membedakan karakteristik daya tahan pemain futsal dari tingkat kompetitif yang berbeda lebih akurat daripada VO2max dan hasil tes kelincahan tim futsal $(50 \%)$ dalam kategori baik, temuan ini menunjukkan masih perlunya

Power otot tungkai team futsal SMA Negeri 3 Mataram (58.3\%), dalam kategori baik, hal ini masih perlu peningkatan lagi. Power otot kaki adalah faktor penting yang diperlukan untuk melompat dan berlari pada atlet (Naser dkk, 2017). Mempertahankan atau meningkatkan kekuatan kaki mungkin penting bagi atlet futsal yang melakukan banyak sprint yang dilakukan secara berulang selama pertandingan yang menyebabkan kelelahan otot yang signifikan.( Dogramaci SN, et al. 2011) Kekuatan otot kaki dapat diperoleh secara tidak langsung dari pengukuran ketinggian maksimal yang dicapai dari suatu CMJ. Meskipun ada lebih sedikit lompatan yang terjadi di dalam futsal, karena permainan membutuhkan lebih banyak umpan darat dari pada sepak bola, itu masih merupakan bagian yang diperlukan untuk kesusksesan. (Silva et al. 2012) menemukan bahwa pemain futsal memiliki kinerja CMJ yang serupa dengan pemain sepak bola sedangkan Gorostiaga et al (.2009) mengamati ketinggian lompatan yang lebih rendah dipemain futsal elit dibandingkan dengan pemain sepak bola elit.

\section{SIMPULAN}


Berdasarkan hasil tes komponen fisik dengan menggunakan 5 kategori tes fisik dominan di antaranya; Daya tahan jantung menggunakan tes (Multistage Test.), Kekuatan otot tungkai menggunakan tes (Leg and Back Dynamometer), Kecepatan menggunakan tes (lari 60 meter), Kelincahan menggunakan tes (Sutel Run Test), dan Daya ledak otot tungkai menggunakan tes (Standing Broad Jump). Tingkat komponen fisik team futsal SMA Negeri 3 Mataram adalah; Data yang dikumpulkan dianalisis menggunakan persentase komulatif. Daya tahan aerobik dengan kategori baik (75\%); kekuatan otot tungkai dalam kategori baik (50\%); kecepatan dalam kategori baik (83.3\%); kelincahan dalam kategori baik (50\%) dan power otot tungkai dalam kategori baik (58.3\%). Kesimpulan kondisi fisik yang dimiliki team futsal SMA Negeri 3 Mataram sebagian besar baik dan perlu ditingkatkan, ada sebagian komponen fisik yang kategori kurang.

\section{DAFTAR PUSTAKA}

Alvarez JC, D'Ottavio S, Vera JG, Castagna C (2009) Aerobic fitness in futsal players of different competitive level. J Strength Cond Res 23:2163-2166

Al-Hazzaa, H.M., Almuzaini, K.S., Al-Refaee, S.A., Sulaiman, M.A., Dafterdar, M.Y., Al-Ghamedi, A., \& AlKhuraiji, K.N. (2001). Aerobic and anaerobic power characteristics of Saudi elite soccer players. Journal of Sports Medicine and Physical Fitness, 41, 54-61.

Bangsbo J, Nørregaard L, Thorsoe F. (1991) Activity profile of competition soccer. Can Journal Sport Sci. 1991; 16:110e116.

Barbero Alvarez J, Soto Hermoso V, Granda Vera J (2004) Effort profiling during indoor soccer competition. $J$ Sports Sci.; 22:500e501

Barbero Alvarez J, Castagna C. (2007) Activity patterns in professional futsal players using global position tracking system. $J$ Sports Sci Med. 6:208e209.
Barbero-Alvarez JC, Soto VM, Granda J (2008) Match analysis and heart rate of futsal players during competition. J Sports Sci 26(1):6373

Castagna C, Impellizzeri FM, Belardinelli R, Abt G, Coutts A et al (2006) Cardiorespiratory responses to YoYo intermittent endurance test in non elite youth soccer players. $J$ Strength Cond Res 20 (2):326-330

Castagna C, D'Ottavio S, Vera JG, BarberoAlvarez JS (2009) Match demands of professional futsal: a case study. J Sci Med

Dogramaci SN, Watsford ML, Murphy AJ. (2011) Time-motion analysis of internationaland national level futsal. J Strength Cond Res.; 25:646e651

Depdiknas. (2000). Pedoman dan Modul Pelatihan Kesehatan Olahraga Bagi Pelatih Olahraga Pelajar. Jakarta.

FIFA. Futsal. [Cited 2012 November 12]; Available from: www.fifa.com

Gorostiaga EM, Llodio I, Iba'nez J, Granados C, Navarro I et al (2009) Differences in physical fitness among indoor and outdoor elite male soccer players. Eur J Appl Physiol 106(4):483-49

Green, S. (1992). Anthropometric and physiological characteristics of south Australian soccer players. Australian Journal of Science and Medicine in Sport, 24, 3-7.

Justinus Lhaksana (2011). Taktik dan Srategi Futsal Modern. Jakarta: Be Champion

McInnes SE, Carlson J, Jones C, et al. (1995) The physiological load imposed on basketball players during competition. Journal Sports Sci. 1995; 13:387e397.

Naser, Ajmol Ali, Paul Macadam. (2017) Physical and physiological demands of futsal. Journal of Exercise Science \& Fitness. 15 (1) 76-80. DOI: 10.1016/j.jesf.2017.09.001

Oliveira RS, Leicht AS, Bishop D, Barbero-A lvarez JC, Naka-mura FY (2013) Seasonal changes in physical 


$$
\begin{aligned}
& \text { performance and heart rate } \\
& \text { variability in high level futsal } \\
& \text { players. Int } J \text { Sports Med } \\
& \text { 34(5):424-430 }
\end{aligned}
$$

Ostojic, S.M., \& Zivanic, S. (2001). Effects of training on anthropometric and physiological characteristics of elite Serbian soccer players. Acta Biologiae et Medicinae Experimentalis, 27, 76

Ostojic, S.M. (2003a). Characteristics of elite and non-elite Yugoslav soccer players: correlates of success. Journal of Sports Science and Medicine, 2, 3435.

Pedro RE, Milanez VF, Boullosa DA, et al. (2013) Running speeds at ventilator threshold and maximal oxygen consumption discriminate futsal competitive level. J Strength Cond Res.; 27:514e518.

Ricardo A. B., Alessandro M, Z., Fabio M., Fabio A, B. (2016) Specific futsal training program can improve the physical performance of futsal players. Sport Sci Health. DOI 10.1007/s11332-016-0283-z

R. Muhammad Tanri, Juliati, Vetriana (2015) Physical Fitness Component Profiles of Futsal Team Members of Universitas Padjadjaran. Althea Medical Journal; 2 (3) 440-447

Sergej M. Ostoji (2000) Physical and physiological Characteristics Of Elite Serbia Soccer Players. Physical Education and Sport. Series: Vol. 1, No 7, pp. 23 -29. UDC 796.332:159.9 (497.11)

Shephard, R. J. (1999). Biology and medicine of soccer: An update. Journal of Sports Sciences, 17, 757-786.

Silva JF, Detanico D, Floriano LT, et al. (2012) Levels of muscle power in soccer and futsal athletes of different categories and positions. Motricidade. $8: 14 \mathrm{e} 22$

Soares-Caldeira LF, de Souza EA, de Freitas VH, de Moraes SM, Leicht AS et al (2014) Effects of additional repeated sprint training during preseason on performance, heart rate variability, and stress symptoms in futsal players: a randomized controlled trial. $J$ Strength Cond Res 28(10):28152826

Ricardo A. B., Alessandro M, Z., Fabio M., Fabio A, B. (2016) Specific futsal training program can improve the physical performance of futsal players. Sport Sci Health. DOI 10.1007/s11332-016-0283-z

Tanri A., Juliati, Vitriana (2015) Physical Fitness Component Profiles of Futsal Team Members of Universitas Padjadjaran in November 2011. Althea Medical Journal; 2 (3): 440 447.

Tomlin DL, Wenger HA. ((2002) The relationship between aerobic fitness and recovery from high intensity intermittent exercise. Sports Med. 2001; 31:1e11. Tomlin $\mathrm{D}$, Wenger $\mathrm{H}$. The relationships between aerobic fitness, power maintenance and oxygen consumption during intense intermittent exercise. Journal of science and medicine in sport, 5pp.194-203.

Ziogas GG, Patras KN, Stergiou N, et al. (2011) Velocity at lactate threshold and running economy must also be considered along with maximal oxygen uptake when testing elite soccer players during preseason. $J$ Strength Cond Res. 2011; $25: 414 \mathrm{e} 419$ 